\title{
Translanguaging as Transformative Pedagogy: Towards a Vision of Democratic Education
}

\section{Translinguagem como pedagogia transformadora: para uma visão de educação democrática}

Sardar M. Anwaruddin*

*York University Toronto / Canada

sardar15@yorku.ca

\begin{abstract}
This paper is a reflection on the use of translanguaging as pedagogy. The primary aim of the paper is to discuss transformative potentials of translanguaging in multilingual educational contexts. To frame the discussion, I turn to Jacques Rancière's critical works, and show how translanguaging may be an effective way of teaching democratic politics in the language classroom.

KEYWORDS: Translanguaging; pedagogy; Rancière; democratic education.

RESUMO: Este trabalho é uma reflexão sobre o uso da translinguagem como pedagogia. O objetivo primário do trabalho é discutir os potenciais transformativos da translinguagem em contextos educacionais multilinguísticos. Para orientar a discussão, este trabalho recorre aos estudos críticos de Jacques Rancière, e mostra como a translinguagem pode ser uma forma eficaz para se ensinar política democrática na sala de aula de idiomas.
\end{abstract}

PALAVRAS-CHAVE: Translinguagem; pedagogia; Rancière; educação democrática.

\section{Introduction}

The concept of translanguaging is gaining increasing attention in the field of language and literacy education. It is particularly intriguing to scholars and educators who are interested in bi/multilingual speakers' language uses in transnational spaces. This essay is a reflection on my use of translanguaging as pedagogy. First, I provide a working definition of translanguaging. I then situate my teaching and the role translanguaging played in it. Reflecting on my experience, I discuss how translanguaging holds 
potential to transform the relationship between the teacher and the student. I also discuss how this transformation may empower the student to develop, express and question various worldviews. I illustrate translanguaging's transformative potential by drawing upon Jacques Rancière's (1991) idea of emancipation and his representation of Joseph Jacotot's teaching. I conclude the essay with some implications for critical language teaching. The overall goal of the essay is to contribute to what Morgan (2014) has described as a reflexive journey towards becoming a critical language teacher.

\section{What is translanguaging?}

Broadly speaking, translanguaging refers to how bi/multilingual speakers draw upon their complex linguistic repertoire for communicative purposes in different contexts. As Sembiante (2016) writes, "translanguaging recognizes speakers' hybrid use of language in alignment with a variety of social purposes and communicative settings and acknowledges their ability to adapt to these diverse sociolinguistic situations" (p. 48). The term translanguaging was derived from Welsh and coined by Cen Williams. Initially, this term was used to refer to "a pedagogical practice where students are asked to alternate languages for the purposes of receptive or productive use" (GARCÍA; KANO, 2014, p. 260). Since the time of its coinage, the term has been used in various ways by different scholars, such as Canagarajah (2011) and Otheguy, García, and Reid (2015). In this essay, translanguaging refers primarily to "the principle that bilingual speakers select language features from a repertoire and 'soft assemble' their language practices in ways that fit their communicative situations" (GARCÍA; KANO, 2014, p. 260). Thus, translanguaging is more than what has been described as code-switching. It involves varied and tactical discursive practices that enable speakers to communicate with each other.

Translanguaging practices may be spontaneous or pre-planned. Studies have shown that translanguaging may be a natural phenomenon for many multilingual students, but the "acts of translanguaging are not [always] elicited by teachers through conscious pedagogical strategies" (CANAGARAJAH, 2011, p. 8). However, other studies have revealed that some teachers take a proactive approach and provide "safe spaces for students to adopt their multilingual repertoire for learning purposes" (CANAGARAJAH, 2011, p. 8). Taking this proactive approach, I was 
concerned with the pedagogical dimension of translanguaging. I was inspired by García and Wei's (2014) conceptualization of translanguaging as "a transformative pedagogy capable of calling forth bilingual subjectivities and sustaining bilingual performances that go beyond one or the other binary logic of two autonomous languages" (p. 92-93). This definition begs the question: what does translanguaging transform? One meaning of transformation that is becoming increasingly relevant is that "semiotic resources transform social structures" and may challenge "understandings of language as regulated or determined by existing contexts of power relations" (CANAGARAJAH, 2018, p. 32). This meaning is important because spaces for dialogue that are required for a strong democracy are disappearing day by day. Liberating language from authoritarian power relations holds the promise of democratic dialogues.

Below, I discuss how translanguaging may transform the relationship between the teacher and the student. I also discuss how this transformation may empower students to articulate and critique different worldviews, which is necessary for democratic politics. I illustrate this potential by drawing on Rancière's (1991) idea of emancipation and his recounting of Jacotot's method of teaching. To achieve this goal, I use the method of reflection on practice.

\section{Why reflect?}

An effective way of professional learning is to reflect on one's own practice. The concept of reflective practice is premised on "the belief that teachers can improve their own teaching by consciously and systematically reflecting on their teaching experiences" (FARRELL, 2008, p. 1). Reflection has always been at the centre of my professional learning and development. My conceptualisation of reflection is based primarily on Paulo Freire's (1970) emancipatory praxis, i.e., "reflection and action upon the world in order to transform it” (FREIRE, 1970, p. 51). In Freire's notion of praxis, true reflection always leads to action. Thus, praxis is a symbiosis between reflection and action (IRWIN, 2012). Freire argued that action without reflection is only activism, and reflection without action is nothing but verbalism. Inspired by the Freirean philosophy of praxis, I use reflection as a method of self-directed professional learning (see ANWARUDDIN, 2015a, for details). In summary, the key objective of reflective practice is 
to learn from past experiences so that they may positively influence future actions (ERAUT, 1994).

\section{Situating my teaching}

In this essay, I refer to a course that I taught at the York University English Language Institute in Toronto, Canada. This course focused on academic reading and writing for pre-university students. All students taking this course were learning English for academic purposes. Many of them were conditionally accepted to various undergraduate programs at York University. Others were preparing for university admission. The majority of students in this class spoke Chinese as their first language. Another group of students' first language was Arabic. All of these students were highly motivated to learn academic English, which was partly reflected in the fact that they had come to a foreign country for higher education. These students' academic success was dependent, to a large extent, on their success in learning the English language.

\section{The teaching of argumentative essay writing}

The segment of teaching that I discuss here is about writing argumentative essays. While teaching this topic, I found it particularly challenging to explain the concepts of counter-argument, refutation and gene mutation. After several attempts of explanation and exemplification, I was not sure if all my students understood the concepts adequately. However, I felt that some students understood the concepts better than others. I noticed that there were at least two students in the Arabic-speaking group, and at least three students in the Chinese-speaking group, who had understood the concepts sufficiently. To make sure that all of my students had understood the concepts, I decided to turn to translanguaging. I put the students into two large groups, based on their first language. In other words, all Arabicspeaking students formed one group and all Chinese-speaking students formed another group. I asked them to discuss the concepts of counterargument, refutation and gene mutation in their mother tongue. By the end of the group-discussions, I felt that all of the students had developed a sufficient understanding of the concepts. 


\section{Challenges of Translanguaging}

The literature on translanguaging reveals numerous benefits of using translanguaging as pedagogy. For example, it provides learners with certain negotiation strategies in multilingual spaces (CANAGARAJAH, 2013). Translanguaging may be an effective tool to disrupt "the hegemony of English in English-medium classrooms" (GARCÍA; KLEYN, 2016, p. 26). Yet translanguaging as pedagogy poses challenges to both teachers and students. As Pacheco and Miller (2015) wrote: "implementing translanguaging pedagogies can be a daunting task, especially when the teacher does not speak students' heritage languages and students speak many different heritage languages in the classroom" (p. 2). This challenge applies to my teaching context, because I speak neither Chinese nor Arabic.

\section{How did I know that the students had understood the concepts?}

After asking the students to discuss the above-mentioned concepts, I ensured that those who had understood the concepts actively participated in the discussions. I joined both groups alternatively, and listened to their discussions (although I did not understand the literal meanings of their discussions). My method of knowing was similar to what Michael Polanyi (2009) described as tacit knowing. Polanyi was among the first philosophers to promote the idea of tacit knowledge or tacit knowing (GASCOIGNE; THORNTON, 2013). Two of his observations are fundamental to understanding the notion of tacit knowledge. First, what is tacit is not tellable. Polanyi's investigation of human knowledge begins with the argument that "we can know more than we can tell" (POLANYI, 2009, p. 4). This argument seems rather obvious, but Polanyi recognizes that "it is not easy to say exactly what it means" (POLANYI, 2009, p. 4). An example that he gave may be illustrative: "We know a person's face, and can recognize it among a thousand, indeed among a million. Yet we usually cannot tell how we recognize a face we know. So most of this knowledge cannot be put into words" (POLANYI, 2009, p. 4). As I observed my students' discussions, I felt that they were having fruitful conversations, geared towards deepening their understanding of the concepts. Once the group discussions ended, I asked the students to share what they had understood. This time, they spoke in English only. The students were able to better explain the concepts, compared to their first attempt prior to participating in the mother-tonguebased discussion groups. 


\section{What did I learn?}

The pedagogical activity briefly described above taught me that translanguaging, when used as a pedagogical principle, transforms the very relationship between the teacher and the student, as well as among the students. It may also contribute to students' intellectual emancipation, which is based on the idea of education as a democratic event. I illustrate this argument, first, by summarizing Rancière's notion of emancipation, and then, by re-telling the story of Jacotot's method of teaching.

Rancière approaches the idea of emancipation from a radically different angle. For him, emancipation is the consciousness of equality, and it "is the process of verification of the equality of intelligence" (RANCIÈRE, 2007, p. 275). Traditionally, emancipatory education has been conceptualized as an intervention, wherein the emancipator empowers the one-to-beemancipated so that the latter can gain a new understanding of oppression and may attempt to release him/herself from the cycles of oppression. Many critical projects have been caught up in this view of emancipation, which ultimately makes the oppressed dependent upon the emancipator. Rancière breaks with this view of emancipation, which denies the equality of intelligence and sows the seeds of mistrust in the interventions of the emancipator. Traditional critical projects, according to Rancière, often end up stultifying those-to-be-emancipated by making them "dependent upon the intervention of the emancipator" (BINGHAM; BIESTA, 2010, p. 31). Thus, emancipation is the opposite of stultification, and stultification happens "whenever one intelligence is subordinated to another" (RANCIÈRE, 1991, p. 13).

At the heart of Rancière's notion of emancipation is equality. However, he does not view equality as a destination. It is a point of departure (for a detailed overview of Rancière's logic of emancipation, see Anwaruddin, 2015b). Rancière (1991) argues that "what stultifies the common people is not the lack of instruction, but the belief in the inferiority of their intelligence" (p. 39). When applied to classroom pedagogies, his philosophy supports educational exchanges between the teacher and the students, which are based upon the maxim of equality. What each party needs to do is to verify that the other's intelligence is equal. This notion of equality leads to "intellectual emancipation as the verification of equality through what is common" and it "provides the substantive foundation for the democratic event" (MEANS, 2011, p. 30). 
Rancière's idea of emancipation can be illustrated through his recounting of Jacotot's teaching method. Jacotot taught Flemish students whose language he did not know, and the students did not know his language either. Jacotot used a bilingual edition of Télémaque (a didactic French novel), gave it to his students, and asked them — through an interpreter — to read the book. He was astonished at the way these students learned French to express themselves. Then, Jacotot proclaimed that "uneducated people could learn on their own, without a teacher explaining things to them, and that teachers, for their part, could teach what they themselves were ignorant of" (RANCIÈRE, 2010, p. 1). Although Jacotot's teaching may seem to echo the principles of what is now known as the grammar-translation method, it actually affirms a radical philosophy of equality and emancipation (ANWARUDDIN, 2017). As Rancière (2010) clarifies, Jacotot "is not an ignorant person who is thrilled by playing teacher" (p. 2). Rather, he is ignorant of an inequality of intelligence. While Jacotot does not transmit knowledge in a traditional sense, he becomes a means of knowledge for his students (RANCIÈRE, 1991). Jacotot's approach not only dissolves the boundary of power between the teacher and the student, but it also respects each individual's social and political right to speak.

The right to speak is fundamental to our social and political existence. As Freire (1970) believed, to change the world, it must first receive a name. The act of naming then necessitates understanding, re-naming and efforts to transform it so that humans can attain significance to their existence and dignity as citizens. Transformation of the world requires saying the true word; however, "saying that word is not the privilege of some few persons, but the right of everyone. Consequently, no one can say a true word alonenor can she say it for another, in a prescriptive act which robs others of their words" (FREIRE, 1970, p. 88). Translanguaging, I argue, takes away this privilege of few people to speak.

\section{Rethinking translanguaging for democratic education}

García and Wei (2014) believe that translanguaging practices disrupt the "binary logic of two autonomous languages," and "changes ways of teaching and ways of learning" (p. 93). When translanguaging is used as pedagogy, the bi/multilingual student "takes control of his or her language practices in order to access texts and knowledge" (p. 93). My decision to 
"give up" my authority of explanation and, instead, to let my students take control of their learning by translanguaging was aligned with García and Wei's (2014) conceptualisation of translanguaging as transformative pedagogy. Jacotot's method of teaching provided me with an interpretive lens to reflect on my pedagogical practice. I did not speak the languages that my students were using during their group discussions. Yet I felt that they benefitted from their collective intelligence. Thus, translanguaging transformed my relationship with the students, because it provided me with a pedagogical resource to encourage them to speak. It helped the students to extend and adapt the repertoire of their semiotic practices in a particular sociolinguistic situation (CREESE; BLACKLEDGE, 2015).

Despite good intentions, some projects of emancipatory education end up stultifying students. Critical pedagogy is not immune to such danger. At times, discourses, such as empowerment and student voice, become what Elizabeth Ellsworth (1989) described as "repressive myths that perpetuate relations of domination" (p. 298). The emancipatory potential of translanguaging, as I view it through the lens of my classroom experience, may provide an alternative to the perpetuation of domination. The teacher's pedagogical goal should not be to simply give up his/her authority in the classroom. Instead, the teacher must trust the students' intelligence. Respecting the student's intelligence is important, because too much 'explanation' in the classroom often reinforces what Rancière (1991) calls the explicative order. Through his pedagogy, Jacotot endeavoured to overturn this explicative order. Commenting on Jacotot's pedagogy, Rancière writes:

Explication is not necessary to remedy an incapacity to understand. On the contrary, that very incapacity provides the structuring fiction of the explicative conception of the world. It is the explicator who needs the incapable and not the other way around; it is he who constitutes the incapable as such. To explain something to someone is first of all to show him he cannot understand it by himself. Before being the act of the pedagogue, explication is the myth of pedagogy, the parable of a world divided into knowing minds and ignorant ones, ripe minds and immature ones, the capable and the incapable, the intelligent and the stupid. (RANCIÈRE, 1991, p. 6)

Thus, the teacher needs to abandon the role of "a sage on the stage" who explains difficult concepts to "ignorant" students as if they are always in need of instruction and 'explication'. 
In the light of Rancière's critical philosophy, my reflection on the teaching of argumentative essays suggests that translanguaging may be used as transformative pedagogy, which holds the potential to disrupt the binary of the "intelligent" and the "stupid." It may provide a powerful pedagogical alternative to practices that are carried out in the name of critical pedagogy but that end up stultifying the learner. These stultifying practices institute dependency in a permanent position as if students are always in a "disadvantaged" situation and in need of interventions from the teacher. Translanguaging as pedagogy always respects the equality of bi/multilingual student's intelligence by encouraging them to draw from a rich repertoire of linguistic resources in a variety of sociolinguistic contexts.

Such encouragement and a relationship of equality between the teacher and the student, I would argue, are necessary to create a condition for critical language teaching. Here, my use of the term "critical" refers to examinations of "how people use texts and discourses to construct and negotiate identity, power and capital” (LUKE, 2004, p. 21). Thus, critical teaching is inherently political. It sheds light on how material and discursive practices of domination are created, distributed and re-created. One key goal of critical language teaching is to examine political discourses in the classroom because the language classroom is a microcosm of the larger society. The classroom provides students with linguistic and conceptual tools to negotiate priorities and develop personal and social identities. Therefore, any political analysis in the classroom should ask: "Who speaks with authority? When, where and how can people respond?" (MORGAN, 1998, p. 23). It follows, then, that an ability to speak freely is foundational to healthy and democratic politics. Translanguaging should be accepted as a conscious attempt to foster such an ability.

In its original sense, the term democracy denoted the power of speaking of those who were not allowed to speak. It is not surprising that democracy was deemed by many as a term of abuse, and that the ability of "demos" to speak was a scandal. As Rancière (2004) wrote, Greek and Trojan leaders denounced the scandal that "men of the demos - men who were part of the indistinct collection of people 'beyond count' - took the liberty of speaking" (p. 5). Pedagogical uses of translanguaging provide such a 'liberty of speaking' to those who would normally remain quiet. The liberty of speaking is necessary, because the contemporary democratic systems of governance are predominantly interest-based and do not allow everyone 
to speak with independent voices. According to common sense, people are less likely to be oppressed when they participate in democratic decision making. However, "an interest-based democratic process allows for the majority to violate the rights of a minority if it seems to be in the majority's interests to do so" (YOUNG, 1993, p. 124). The minority, therefore, needs to be able to speak out for themselves. Translanguaging practices may be an effective way of doing so. In the classroom context, as well as in the larger sociopolitical arena, translanguaging is inherently empowering, because it makes linguistic arrangements "around experiences that are immediate to students" (MORGAN, 1998, p. 19). By taking the "demos" into account, translanguaging opens the door of democratic education by listening to diverse voices. Being able to speak freely, the students may join a social space where "the political can always surge...in the work of reconfiguring the givens” (RANCIÈRE, 2016, p. 125). Thus, translanguaging as a pedagogical practice holds the potential to encourage students to engage with "worlds and words created by the coloniality of power” (GARCÍA, 2017, p. 17).

\section{References}

ANWARUDDIN, S. M. Teacher Professional Learning in Online Communities: Toward Existentially Reflective Practice. Reflective Practice: International and Multidisciplinary Perspectives, Taylor \& Francis Online, v. 16, n. 6, p. 806-820, 2015 a.

ANWARUDDIN, S. M. Pedagogy of Ignorance. Educational Philosophy and Theory, Taylor \& Francis Online, v. 47, n. 7, p. 734-746, 2015 b.

ANWARUDDIN, S. M. (2017). Methodism versus teacher agency in TESOL. In: RIVERS, D; ZOTZMANN, K (Org.). Isms in Language Education: Oppression, Intersectionality and Emancipation. Berlin: De Gruyter, 2017. p. 144-164. Doi: ttps://doi.org/10.1515/9781501503085-008

BINGHAM, C.; BIESTA, G. Jacques Rancière: Education, truth, emancipation. New York: Continuum, 2010.

CANAGARAJAH, S. Translanguaging in the classroom: Emerging issues for research and pedagogy. Applied Linguistics Review, De Gruyter, v. 2, p. 1-28, 2011.

CANAGARAJAH, S. Translingual practice: Global Englishes and cosmopolitan relations. New York: Routledge, 2013.

CANAGARAJAH, S. Translingual practice as spatial repertoires: Expanding the paradigm beyond structuralist orientations. Applied Linguistics, Oxford, v. 39, n. 1, p. 31-54, 2018. Doi: https://doi.org/10.1093/applin/amx041 
CREESE, A.; BLACKLEDGE, A. Translanguaging and identity in educational settings. Annual Review of Applied Linguistics, Cambridge, v. 35, p. 20-35, 2015. Doi: https://doi.org/10.1017/S0267190514000233

ELLSWORTH, E. Why doesn't this feel empowering? Working through the repressive myths of critical pedagogy. Harvard Educational Review, Cambridge, v. 59, n. 3, p. 297-324, 1989. Doi: https://doi.org/10.17763/haer.59.3.058342114k266250 ERAUT, M. Developing professional knowledge and competence. London: Falmer Press, 1994.

FARRELL, T.S. C. Reflective practice in the professional development of teachers of adult English language learners. CAELA Network Brief, 2008. Available at $<$ http://www.cal.org/caelanetwork/resources/reflectivepractice.html $>$. Retrieved May 2, 2018.

FREIRE, P. Pedagogy of the oppressed. New York: Continuum, 1970.

GARCÍA, O. Bilingual education in the 21 st century: A global perspective. Malden: Wiley-Blackwell, 2009.

GARCÍA, O. Problematizing linguistic integration of migrants: the role of translanguaging and language teachers. In: BEACCO, J-C.; KRUMM, H-J.; LIT'TLE, D.; THALGOT'T, P. (Org.). The linguistic integration of adult migrants: some lessons from research. Berlin: De Gruyter, p. 11-26, 2017. Doi: https:/ / doi.org/10.1515/9783110477498-005

GARCÍA, O.; KANO, N. Translanguaging as process and pedagogy: Developing the English writing of Japanese students in the US. In: CONTEH, J.; MEIER, G. (Org.). The multilingual turn in languages education: Benefits for individuals and societies. Bristol: Multilingual Matters, 2014. p. 258-277.

GARCÍA, O.; KLEYN, T. Translanguaging with multilingual students: Learning from classroom moments. New York: Routledge, 2016.

GARCÍA, O.; WEI, L. Translanguaging: Language, bilingualism and education. New York: Palgrave Macmillan, 2014.

GASCOIGNE, N.; THORNTON, T. Tacit knowledge. New York: Routledge, 2013. IRWIN, J. Paulo Freire's philosophy of education: Origins, developments, impacts and legacies. New York: Continuum, 2012.

LUKE, A. Two Takes on the Critical. In: NORTON, B.; TOOHEY, K. (Org.). Critical pedagogies and language learning. Cambridge: Cambridge University Press, 2004. p. 21-31. Doi: https://doi.org/10.1017/CBO9781139524834.002 
MEANS, A. Jacques Rancière, education, and the art of citizenship. Review of Education, Pedagogy, and Cultural Studies, Cambridge, v. 33, n. 1, p. 28-47, 2011. Doi: https://doi.org/10.1080/10714413.2011.550187

MORGAN, B. The ESL Classroom: Teaching, critical practice, and community development. Toronto: University of Toronto Press, 1998. Doi: https://doi. org $/ 10.3138 / 9781442681200$

MORGAN, B. Becoming a critical language teacher: A reflexive journey. Revista Diálogos Interdisciplinares - GEPFIP, Aquidauana, MS, v. 1, n. 1, p. 21-32, 2014.

OTHEGUY, R.; GARCÍA, O.; REID, W. Clarifying translanguaging and deconstructing named languages: A perspective from linguistics. Applied Linguistics Review, De Gruyter, v. 6, n. 3, p. 281-307, 2015.

PACHECO, M. B.; MILLER, M. E. Making meaning through translanguaging in the literacy classroom. The Reading Teacher, Wiley Online Library, v. 69, n. 5, p. 533-537, 2015.

POLANYI, M. The tacit dimension. Chicago: The University of Chicago Press, 2009.

RANCIÈRE, J. The Ignorant Schoolmaster: Five lessons in intellectual emancipation. Trans. K. Ross. Stanford: Stanford University Press, 1991.

RANCIÈRE, J. Introducing disagreement. Angelaki: Journal of the Theoretical Humanities, Taylor \& Francis Online, v. 9, n. 3, p. 3-9, 2004.

RANCIÈRE, J. The emancipated spectator. Arfforum, New York, v. 45, p. 270-280, 2007.

RANCIÈRE, J. On ignorant schoolmasters. In: BINGHAM, C.; BIESTA, G. (Org.). Jacques Rancière: Education, truth, emancipation. New York: Continuum, 2010. p. 1-24.

RANCIÈRE, J. The method of equality. Trans. J. Rose. Cambridge: Polity Press, 2016.

SEMBIANTE, S. Translanguaging and the multilingual turn: Epistemological reconceptualization in the fields of language and implications for reframing language in curriculum studies. Curriculum Inquiry, Francis \& Taylor Online, v. 46, n.1, p. 45-61, 2016. Doi: https://doi.org/10.1080/03626784.2015.1133221

YOUNG, I. M. Justice and communicative democracy. In: GOTTLIEB, R. S. (Org.). Radicalphilosophy: Tradition, counter-tradition, politics. Philadelphia: Temple University Press, 1993. p. 123-143.

Data de submissão: 30/05/2017. Data de aprovação: 27/04/2018. 